\title{
Different prevalences of Renibacterium salmoninarum detected by ELISA in Alaskan chinook salmon Oncorhynchus tshawytscha spawned from freshwater and seawater
}

\author{
T. R. Meyers ${ }^{1, *}$, F. Thrower ${ }^{2}$, S. Short ${ }^{1}$, K. Lipson ${ }^{1}$, J. Joyce ${ }^{2}$, C. Farrington $^{3}$, \\ S. Doherty ${ }^{4}$ \\ ${ }^{1}$ Alaska Department of Fish and Game, Commercial Fisheries Division, PO Box 25526, Juneau, Alaska 99802-5526, USA \\ ${ }^{2}$ National Marine Fisheries Service, Auke Bay Laboratory, 11305 Glacier Highway, Juneau, Alaska 99801, USA \\ ${ }^{3}$ Alaska Department of Fish and Game, Commercial Fisheries Division, 802 3rd Street, PO Box 240020, Douglas, \\ Alaska 99824-0020, USA \\ ${ }^{4}$ Southern Southeast Regional Aquaculture Association, 2721 Tongass Avenue, Ketchikan, Alaska 99901, USA
}

\begin{abstract}
Soluble antigen of Renibacterium salmoninarum (Rs) was detected by a polyclonal enzyme-linked immunosorbent assay (ELISA) at significantly higher prevalences in adult chinook salmon Oncorhynchus tshawytscha that matured in freshwater than in the same cohort of fish spawned after maturation in seawater. The cumulative results were consistent during $4 \mathrm{yr}$ of comparison at the Little Port Walter Hatchery on Baranof Island, Alaska, USA. Possible causes for this difference are discussed. Maturation of chinook salmon broodstock in seawater has become a practical strategy at this hatchery to reduce the prevalence of Rs-positive parent fish and the numbers of culled eggs.
\end{abstract}

KEY WORDS: Renibacterium $\cdot$ ELISA $\cdot$ Chinook

\section{INTRODUCTION}

The enzyme-linked immunosorbent assay (ELISA) has been used successfully to measure the prevalence and levels of Renibacterium salmoninarum (Rs) infection among different stocks of Alaskan salmon (Meyers et al. 1993a, b). Eggs from the matings of Rs-positive salmonids are destroyed or segregated at certain Alaskan hatcheries to help reduce vertical transmission (Evelyn et al. 1984a, c) of the pathogen and resulting bacterial kidney disease (BKD) in progeny fish. One such facility where eggs are culled annually from Rs-positive adult chinook salmon Oncorhynchus tshawytscha is the Little Port Walter (LPW) federal salmon hatchery on Baranof Island, Alaska, USA. The success

\footnotetext{
•E-mail: fishpath\%fishgame@state.ak.us
}

of broodstock maturation in seawater at this facility was compared to that of maturation in freshwater because seawater netpens could be placed closer to the hatchery for more convenient handling of adult fish and would increase broodstock holding capacity. During this study, a greater prevalence of Rs antigen was detected in the adult chinook salmon spawned from freshwater when compared to the same cohort of fish spawned after maturation in seawater netpens.

\section{MATERIALS AND METHODS}

Fish in freshwater. Adult chinook salmon were captured annually at the end of June during 1988 to 1992 by purse or drop seine from intertidal areas near the hatchery and from a weir on Sashin Creek, the source of freshwater for the hatchery. Fish were moved by 
dipnet into 5 square nylon nets each having a volume of $36.8 \mathrm{~m}^{3}$. These nets were located in a freshwater concrete/earthen holding pond of $10 \times 15 \mathrm{~m}$ with a water depth of $2.6 \mathrm{~m}$. Between 75 to 100 fish were held in each of the 5 nets at densities of approximately $20 \mathrm{~kg}$ $\mathrm{m}^{-3}$. Water supplied from an intake above the weir in Sashin Creek produced an exchange rate in the holding pond of 0.67 to 1.1 total volume $h^{-1}$ and a water temperature between 12 and $16^{\circ} \mathrm{C}$. These fish matured after 1 to 2 mo and were spawned throughout August of each year

Fish in seawater. From 1989 to 1992 some of the same stock of adult chinook salmon caught intertidally by commercial purse seine were also held in seawater netpens in front of the hatchery to compare the success of gamete maturation with that achieved from the same cohort of fish held in freshwater. All fish that matured in seawater netpens were spawned in late August after 1 to 2 mo of confinement. During 1989 to 1992, returning adult chinook salmon were examined by ELISA 2 d after capture from seawater. These data were used to determine the baseline prevalence of Rs antigen in 'ocean bright' fish prior to sexual maturation.

During each test year, 400 to 1000 fish were placed into 1 seawater netpen of $1352 \mathrm{~m}^{3}$ with $1.5 \mathrm{~cm}$ square mesh and a natural freshwater lens from Sashin Creek. The depth of the natural lens was generally $0.5 \mathrm{~m}$ and was too shallow for significant numbers of adult fish to remain there. The fish density for the total netpen volume was 2.5 to $6.3 \mathrm{~kg} \mathrm{~m}^{-3}$. Summer salinities ranged from 29 to $31 \mathrm{ppt}$ below the freshwater lens. Total water depth at the netpen site ranged from 7.6 to $12.2 \mathrm{~m}$. The exchange rate was not known for the seawater netpen. However, a conservative estimated mean tidal fluctuation of $2 \mathrm{~m}$ at the netpen site should have provided a constant flow of water greater than that 11 exchange $\mathrm{h}^{-1}$ ) for the freshwater group of fish in Sashin Creek. Average seawater temperatures were 9 to $12^{\circ} \mathrm{C}$. During 1989 to 1992 a second seawater treatment group of 125 to 150 fish was held in a seawater netpen $\left(301 \mathrm{~m}^{3}\right)$ supplied with an artificial freshwater lens $1 \mathrm{~m}$ in depth (Thrower 1993). This lens was produced from a pipeline that delivered $200 \mathrm{gal} \mathrm{min}^{-1}$ (ca $760 \mathrm{l} \mathrm{min}^{-1}$ ) of freshwater from Sashin Creek into a netpen which had a $1 \mathrm{~m}$ wide plastic skirt suspended vertically from the float collar. The exchange rate in this freshwater lens was about 0.75 total volume $\mathrm{h}^{-1}$. Captive fish tended to remain in the freshwater lens, producing fish densities of 17 to $20 \mathrm{~kg} \mathrm{~m}^{-3}$. Otherwise, the fish density for the entire netpen was less and was similar to that of the first seawater treatment group of fish. In 1989, water for the artificial freshwater lens came directly from the freshwater maturation pond containing broodfish in Sashin Creek. Each year thereafter, water was supplied from above the weir in Sashin Creek beyond anadromous fish access.

Seawater maturation was most successful in netpens with an artificial freshwater lens (Thrower unpubl. data) and the prevalence of Rs antigen was significantly reduced. Hence, this method was used for the maturation of all returning chinook salmon broodstock after 1992 with annual monitoring of Rs antigen by ELISA.

ELISA and FAT. Kidney tissue was examined by ELISA as described by Meyers et al. (1993b). Kidney samples producing ELISA optical density (OD) values $\geq 0.095$ were considered positive for the Rs antigen. Kidney tissues having higher ELISA OD values approaching 1.0 were examined by the indirect and the direct fluorescent antibody tests (FAT) to confirm the presence of the Rs organism (Meyers et al. 1993a). The direct FAT used the same anti-Rs antiserum as the ELISA, but the antiserum was conjugated with fluorescein isothiocyanate instead of horseradish peroxidase.

Toward the end of spawning operations in 1995 , freshwater samples were collected for ELISA and FAT to help evaluate the unexpected high prevalence of Rs antigen detected that year in broodfish from the seawater netpens. Sampled water came from the main waterline entering the hatchery, the Sashin Creek freshwater maturation pond and the artificial freshwater lens in 1 seawater netpen where a small number of unspawned broodfish still remained. Although the freshwater maturation pond was not used for chinook salmon broodstock after 1992, a few returning fish still gained access to this area annually and were present when water was sampled. The approximate volume of each freshwater sample was 1 l, from which 2 undiluted $2 \mathrm{ml}$ aliquots were processed for ELISA, 1 unfiltered and 1 after passage through a $0.45 \mu \mathrm{m}$ filter. Direct filtration FAT for detection of Rs organisms (Elliott \& Barila 1987) was performed on a third $2 \mathrm{ml}$ aliquot from each raw water sample. Prior to filtration FAT, raw water samples were refrigerated overnight to allow some settling of suspended materials. Test aliquots were collected from the sediments since they were most likely to contain associated bacteria.

Statistical analysis. Statistical comparisons of Rs antigen prevalences were done using arcsine transformation of proportions compared to probability values in a 2 -tailed distribution table (Sokal \& Rohlf 1969). We opted to use a conservative probability level by which values were significantly different when $p<0.005$.

\section{RESULTS}

During 1988, fish were matured in freshwater alone, resulting in a $47 \%$ (78/167 fish) prevalence of Rs anti- 
gen with $78 \%$ of the Rs-positive fish having low mean OD values of less than 0.2. During 1989 to 1991 the prevalences of Rs antigen in the chinook salmon spawned from freshwater were higher $(p<0.001)$ than those of fish spawned from the seawater netpen with a natural freshwater lens (Table 1). In 1992 the sample size of fish from freshwater was too small for statistical comparison with other experimental groups.

The cumulative results for 1989 to 1992 also indicated a higher prevalence $(\mathrm{p}<0.001)$ of Rs-positive fish spawned from freshwater when compared to fish that matured in both seawater groups (Table 1). Fish in the seawater netpen with an artificial lens had a higher prevalence $(p<0.001)$ of Rs antigen than fish in the seawater netpen with a natural freshwater lens. No other differences $(p>0.005)$ in the cumulative prevalence of Rs antigen occurred among the seawater groups of fish (Table 1). A high percentage of the Rspositive fish in all experimental groups had low ELISA OD values that were less than 0.2 (Table 1). However, Rs-positive fish were too few in the seawater netpens (Table 1) to allow valid statistical comparisons.

Despite an empirically high value in 1990, the prevalences of Rs antigen during 1989 to 1992 in the baseline 'ocean bright' fish were not different $(p>0.005)$ from those of fish that matured in seawater netpens having a natural freshwater lens (Table 1).

Table 1. Renibacterium salmoninarum (Rs) infecting Oncorhynchus tshawytscha. Soluble antigen of Rs (prevalence [\%]; numbers given in parentheses) detected by ELISA in adult Alaskan chinook salmon prior to gonad maturation in seawater and after spawning from freshwater and seawater at Little Port Walter, Alaska, during 1989 to 1992 .

\begin{tabular}{ccccc} 
Year & \multicolumn{5}{c}{ Treatment groups } \\
& Ocean Bright & Seawater/lens natural & Freshwater & Seawater/lens artificial \\
\hline 1989 & 1.7 & 1.8 & 25.3 & 2.0 \\
& $(1 / 60)$ & $(3 / 165)$ & $(70 / 277)$ & $(1 / 51)$ \\
& $0^{\mathrm{a}}$ & $66.6^{\mathrm{a}}$ & $72.9^{\mathrm{a}}$ & $100^{\mathrm{a}}$ \\
& & $(2 / 3)$ & $(51 / 70)$ & $(1 / 1)$ \\
1990 & 16.7 & 2.2 & 58.1 & 21.4 \\
& $(10 / 60)$ & $(1 / 45)$ & $(229 / 394)$ & $(12 / 56)$ \\
& $100.0^{\mathrm{a}}$ & $0^{\mathrm{a}}$ & $77.7^{\mathrm{a}}$ & $83.3^{\mathrm{a}}$ \\
& $(10 / 10)$ & & $(178 / 229)$ & $(10 / 12)$ \\
1991 & 0 & 0.9 & 16.6 & 16.9 \\
& $(0 / 60)$ & $(4 / 429)$ & $(29 / 174)$ & $(20 / 118)$ \\
& & $100^{\mathrm{a}}$ & $82.8^{\mathrm{a}}$ & $20.0^{\mathrm{a}}$ \\
& & $(4 / 4)$ & $(24 / 29)$ & $(4 / 20)$ \\
1992 & 1.6 & 0 & 9.0 & 1.2 \\
& $(3 / 187)$ & $(0 / 46)$ & $(1 / 11)$ & $(3 / 258)$ \\
& $100^{\mathrm{a}}$ & & $0^{\mathrm{a}}$ & $100^{\mathrm{a}}$ \\
& $(3 / 3)$ & & & $(3 / 3)$ \\
Total & 3.8 & 1.2 & 38.4 & 7.4 \\
& $(14 / 367)$ & $(8 / 685)$ & $(329 / 856)$ & $(36 / 483)$ \\
Total & 92.8 & 75.0 & 76.9 & 50.0 \\
& $(13 / 14)$ & $(6 / 8)$ & $(253 / 329)$ & $(18 / 36)$
\end{tabular}

${ }^{a}$ Percent of Rs-positive fish with low mean optical density values $<0.2$
Annual Rs prevalences varied considerably for fish in the seawater netpen with an artificial freshwater lens (Table 1). The lower Rs prevalences in 1989 and 1992 were not different $(p>0.005)$ from those of fish in the natural lens netpen, while in 1990 and 1991 the prevalences were higher $(\mathrm{p}<0.005$ and $\mathrm{p}<0.001$, respectively). The high prevalence in 1991 was equal to that for the fish spawned from freshwater, whereas the 1990 prevalence was lower $(\mathrm{p}<0.001$; Table 1$)$. In $1993(1 \% ; 7 / 542)$ and $1994(2 \% ; 16 / 661)$ the Rs prevalences were again low in fish from seawater netpens with an artificial freshwater lens, but there were no other test groups of fish for comparison. The 2 yr of low prevalence in the artificial lens group changed in 1995 when nearly $45 \%(309 / 688)$ of spawned fish were Rspositive.

All 3 freshwater samples collected in 1995 were ELISA-positive for Rs antigen before and after filtration (Table 2). The lowest level of Rs antigen was detected in the hatchery water supply. This result was not unexpected because rainbow trout Oncorhynchus mykiss previously examined from that watershed had a high prevalence $(81 \%)$ of Rs antigen with very high OD values (Alaska Department of Fish and Game unpubl.). The artificial freshwater lens from the seawater netpen had the highest ELISA OD value for Rs antigen. This observation was consistent with current hatchery operations in which the greatest fish densities occurred in the artificial lens rather than in the freshwater pond of Sashin Creek. No Rs cells were observed in the raw water samples when examined by direct filtration FAT.

Typical Rs cells were detected by FAT in the kidney tissues from fish in seawater and freshwater when corresponding ELISA OD values were $\geq 1.0$ (Meyers et al. 1993a). No crossreacting bacteria were observed by the FAT in kidney tissues or water samples that could potentially have confounded the ELISA results

\section{DISCUSSION}

Data from a 4 yr comparative study indicated that the prevalences of Rs antigen in chinook salmon matured in seawater netpens with natural or artificial freshwater lenses were comparable to the low prevalence of baseline 'ocean bright' fish and much lower than the high prevalence ob- 
Table 2. Average ELISA optical density values of Rs-positive unfiltered and filtered $(0.45 \mu \mathrm{m})$ freshwater samples from the Little Port Walter Hatchery in 1995

\begin{tabular}{lcc|}
\hline Freshwater source & Unfiltered & Filtered \\
\hline Hatchery pipeline & 0.141 & 0.184 \\
Sashin Creek maturation pond & 0.265 & 0.224 \\
Seawater netpen/artificial lens & 0.643 & 0.642 \\
\hline
\end{tabular}

served in fish matured conventionally in freshwater. The higher prevalences of Rs antigen in fish that matured in freshwater may have been due to the more stressful holding conditions. Physiological stress can enhance the expression of Renibacterium salmoninarum in carrier fish as well as the horizontal transmission of viable bacteria to uninfected fish (Austin \& Austin 1987). The freshwater group of fish had lower water exchange rates and were exposed to higher water temperatures and greater fish densities than occurred in the natural lens seawater netpens. During some years these stressful conditions occurred to a lesser degree in the seawater netpen which had the deeper artificial freshwater lens. This lens attracted fish in higher densities than would occur if they utilized the entire netpen volume. Sporadic occurrence of poor lens conditions due to weather and tides may enhance horizontal transmission of Rs in the artificial freshwater lens. The variability in transmission could explain fluctuations in the annual prevalence of Rs antigen and the cumulative prevalence of Rs-positive fish that was higher than that observed in fish spawned from the seawater netpen with the natural lens. Support for this rationale comes from a study (Pascho et al. 1997 ) in which rainbow trout were exposed to live $R$. salmoninarum and the resulting ELISA OD values of kidney tissues were examined. A brief $24 \mathrm{~h}$ waterborne exposure to high concentrations $\left(10^{5}\right.$ to $10^{6}$ cells $\left.\mathrm{ml}^{-1}\right)$ of washed Rs cells resulted in low (0.074 to 0.199) and medium (0.200 to 0.999) Rs-positive ELISA OD values in the kidney tissues of fish $50 \mathrm{~d}$ post-exposure. Other results imply that these fish were infected by Rs organisms. Fish in the same study exposed to a low concentration of Rs cells $\left(10^{3} \mathrm{ml}^{-1}\right)$ had kidney tissues that were negative for Rs antigen (Pascho et al. 1997). Our fish were probably exposed to diluted concentrations of Rs cells, but for a longer duration, which could have been sufficient to infect fish and contribute to the elevated ELISA OD values we observed. However, the likelihood of this explanation is limited by the low efficiency of horizontal transmission of $R$. salmoninarum by cohabitation (Murray et al. 1992) and by the slow progression of the disease when fish become infected (Bell et al. 1984, Murray et al. 1992). Conversely, it is plausible that exposure of fish to soluble Rs antigen in the freshwater used at the hatchery may also have contributed to low level Rs-positive kidney tissues. The Rspositive OD values in freshwater appeared to increase with increasing fish densities where the prevalence of Rs-positive fish was high. We acknowledge that the water samples tested in 1995 may not have been representative of events occurring earlier during the comparative study and that seawater should also have been examined for Rs antigen. It is also possible that filtration FAT may not have detected low numbers of a potentially crossreacting organism in the water that could have confounded the ELISA. However, our experience with this ELISA has not demonstrated crossreacting organisms associated with routine fish culture in Alaska (Meyers et al. 1993a, b). In spite of these arguments we suggest that test-negative fish in freshwater could passively adsorb soluble Rs antigen associated with Rs cells released from infected fish when water exchange rates are low and fish densities are high. Again, the soluble antigen would be extremely diluted by ambient water but bioaccumulation of low levels in kidney tissues that are detectable by our ELISA ( $\geq 20 \mathrm{ng} \mathrm{ml}^{-1}$; Meyers et al, 1993b) is feasible during continual exposure of fish for several weeks. Fish rapidly adsorb (Smith 1988) certain Gram-negative and Gram-positive bacterial antigens from ambient water through the gills (Alexander et al. 1981, Smith 1982) or by drinking water containing the antigens (Robohm \& Koch 1995). These antigens accumulate in various fish tissues including the kidney (Nelson et al. 1985). This adsorptive mechanism was the basis for water immersion vaccination trials (Amend \& Johnson 1981, Amend et al. 1983), which were not successful against the Rs organism due to failed protection from natural challenges and unconvincing serological results (Paterson et al. 1981, Evelyn 1984b, McCarthy et al. 1984). These studies and others (Pascho et al. 1997) have shown that Rs antigens are weak immunogens in fish (Elliott et al. 1989), but these data do not indicate a lack of Rs antigen uptake. The latter has not been adequately evaluated by direct measurement for the presence of adsorbed antigen after vaccination but instead has been examined indirectly by measurement of an inadequate host immune response. Passive adsorption of Rs antigen also raises the question of whether all ELISA-positive fish are infected with viable organisms, an important issue for making disease policy decisions.

During August 1997 at another hatchery on Baranof Island, Alaska, we again observed an instance where significant differences occurred in Rs prevalences between chinook salmon spawned from freshwater and seawater. In this case, chinook salmon were confined for a shorter maturation period of up to $3 \mathrm{wk}$. Afterwards the same cohort of fish was spawned from fresh- 
water raceways and from a seawater netpen ( $29 \mathrm{ppt}$ ) in the estuary near the hatchery effluent. The prevalence of Rs antigen in fish spawned from the freshwater raceways was higher $(\mathrm{p}<0.001)$ at $32.7 \%(350 / 1071)$ when compared to $5.2 \%(20 / 382)$ in fish spawned from the seawater netpen (Alaska Department of Fish and Game unpubl.).

The specific conditions responsible for these different ELISA data in freshwater and seawater require further investigation. Until then, fish culturists who do not have the option of maturing fish in seawater should note the importance of optimizing the freshwater maturation environment to minimize the prevalence of Rs antigen in adult chinook salmon. This is important if eggs are being segregated or culled from Rs-positive broodfish based on ELISA.

Acknowledgements. This study was funded in part by the Alaska Department of Fish and Game, Commercial Fisheries Division, and the National Marine Fisheries Service, Auke Bay Laboratory. We also thank Dr Diane Elliott and Ron Pascho for their helpful reviews of an earlier draft of this manuscript.

\section{LITERATURE CITED}

Amend DF, Johnson KA (1981) Current status and future needs of Vibrio anguillarum bacterins. Dev Biol Standard 49:403-417

Amend DF, Johnson KA, Croy TR, McCarthy DH (1983) Some factors affecting the potency of Yersinia ruckeri bacterins $\mathrm{J}$ Fish Dis 6:337-344

Alexander JB, Bowers DA, Shamshoom SM (1981) Hyperosmotic infiltration of bacteria into trout: route of entry and the fate of the infiltrated bacteria. Dev Biol Standard 49: $441-445$

Austin B, Austin DA (1987) Bacterial fish pathogens. Ellis Horwood Limited, Chichester, p 70-87

Bell GR, Higgs DA, Traxler GS (1984) The effect of dietary ascorbate, zinc, and manganese on the development of experimentally induced bacterial kidney disease in sockeye salmon (Oncorhynchus nerka). Aquaculture 36: $293-311$

Elliott DG, Barila TY (1987) Membrane filtration-fluorescent antibody staining procedure for detecting and quantifying Renibacterium salmoninarum in coelomic fluid of chinook salmon (Oncorhynchus tshawytscha). Can J Fish Aquat Sci 44:206-210

Elliott DG, Pascho RJ, Bullock GL (1989) Developments in the control of bacterial kidney disease of salmonid fishes. Dis Aquat Org 6:201-215

Evelyn TPT, Ketcheson JE, Prosperi-Porta L (1984a) Further evidence for the presence of Renibacterium salmoninarum in salmonid eggs and for the failure of povidone-iodine to reduce the intra-ovum infection rate in water-hardened eggs. J Fish Dis 7:173-182

Evelyn TPT, Ketcheson JE, Prosperi-Porta L (1984b) On the feasibility of vaccination as a means of controlling bacterial kidney disease in Pacific salmon. Abstracts, International Conference on the Biology of Pacific Salmon, 5-12 September 1984, Victoria/Agassiz, British Columbia

Evelyn TPT, Prosperi-Porta L, Ketcheson JE (1984C) The salmonid egg as a vector of the kidney disease bacterium, Renibacterium salmoninarum. In: ACUIGRUP (ed) Fish diseases, 4th COPRAQ Session, Editora ATP, Madrid, p $111-117$

McCarthy DH, Croy TR, Amend DF (1984) Immunization of rainbow trout, Salmo gairdneri Richardson, against bacterial kidney disease: preliminary efficacy evaluation. J Fish Dis 7:65-71

Meyers TR, Short S, Farrington C, Lipson K, Geiger HJ, Gates $\mathrm{R}$ (1993a) Comparison of the enzyme-linked immunosorbent assay (ELISA) and the fluorescent antibody test (FAT) for measuring prevalences and levels of Renibacterium salmoninarum in wild and hatchery stocks of salmonid fishes in Alaska, USA. Dis Aquat Org 16:181-189

Meyers TR, Short S, Farrington C, Lipson K, Geiger HJ, Gates $\mathrm{R}$ (1993b) Establishment of a negative-positive threshold optical density value for the enzyme-linked immunosorbent assay (ELISA) to detect soluble antigen of Renibacterium salmoninarum in Alaskan Pacific salmon. Dis Aquat Org 16:191-197

Murray CB, Evelyn TPT, Beacham TD, Barner LW, Ketcheson JE, Prosperi-Porta L (1992) Experimental induction of bacterial kidney disease in chinook salmon by immersion and cohabitation challenges. Dis Aquat Org 12:91-96

Nelson JS, Rhovec JS, Fryer JL (1985) Tissue location of vibrio bacterin delivered by intraperitoneal injection, immersion and oral routes to Salmo gairdneri. Fish Pathol 19:263-269

Pascho RJ, Goodrich TD, McKibben CL (1997) Evaluation by enzyme-linked immunosorbent assay (ELISA) of Renibacterium salmoninarum bacterins affected by persistence of bacterial antigens. J Aquat Anim Health 9:99-107

Paterson WD, Desautels D, Weber JM (1981) The immune response of Atlantic salmon, Salmo salar L, to the causative agent of bacterial kidney disease, Renibacterium salmoninarum. J Fish Dis 4:99-111

Robohm RA, Koch RA (1995) Evidence for oral ingestion as the principal route of antigen entry in bath-immunized fish. Fish Shellfish Immunol 5:137-150

Smith PD (1982) Analysis of the hyperosmotic and bath methods for fish vaccination-comparison of uptake of particulate and non-particulate antigens. Dev Comp Immunol (Suppl 2):181-186

Smith PD (1988) Vaccination against vibriosis. In: Ellis AE (ed) Fish vaccination. Academic Press, New York, p 67-84

Sokal RR, Rohlf FJ (1969) Biometry. WH Freeman and Company, San Francisco, p 607-608

Thrower FP (1993) Gamete viability of ocean-ranched and farmed steelhead. In: Reinentsen H, Dahle L Andre, Jørgensen $\mathrm{L}$, Tvinneneini $\mathrm{K}$ (eds) Proc First Int Conf Fish Farming Technol, August, 1993, Trondheim

Submitted: May 26, 1998; Accepted: October 23, 1998

Proofs received from author(s): January 21, 1999
Editorial responsibility: David Bruno,

Aberdeen, Scotland, UK 